\title{
The Development of Social Capital Through International Students' Involvement in Campus Organizations
}

\section{Chris Glass $^{\mathrm{a}}$ and Peggy Gesing ${ }^{\mathrm{b}}$}

\begin{abstract}
This study examined campus organization involvement as a mechanism for social capital development. Researchers used analysis of variance (ANOVA) to examine variations in network size, strength, and composition for international students involved in different types of campus organizations. Researchers also examined the relationship of campus organization involvement to international students' sense of attachment to the university. Students who participated in majorbased organizations or leadership programs had larger, less dense, more diverse networks that lead to social networks which are particularly advantageous to social mobility. Students who participated in campus organizations related to their own cultural heritage had networks built of friends from all cultures, creating a greater sense of belonging and attachment to the university. Implications of social capital for practice and future research are discussed.
\end{abstract}

Keywords: attachment, belonging, co-curricular engagement, social capital, social networks, international students

\section{Introduction}

International students gain a sense of community through social interactions with host country students, other international students, and co-national students (Rienties and Nolan, 2014). Relationships with faculty and peers not only assist with adaptation to college, they are the source of resources that facilitate that adaptation (Glass et al., 2017). In recent years, researchers have urged research that unpacks how groups facilitate the social and academic adaptation of international students. Previous studies of international student networks have found that social involvement is significantly associated with the

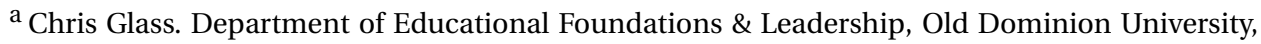
Email: crglass@odu.edu

b Peggy Gesing. Department of Educational Foundations \& Leadership, Old Dominion University, Email: mgesing@odu.edu
} 
development of social capital, practical and socioemotional resources embedded in social networks (Beech, 2015; Lin et al., 2011; Trice, 2004).

Building upon recent work on international student networks, this article examines how the size, density, composition, and strength of social networks in academic programs, cocurricular organizations, families, and residential communities are determinants for the nature of the social capital developed during academic study (Yao, 2016). Social capital, in this sense, does not merely represent resources which may assist international students in their adaptation to college, but access to social capital is itself also a major outcome of college, and perhaps the most significant outcome of college (Adler and Kwon, 2002). When a university degree is conferred, it not only certifies the completion of an academic program, it also identifies the student's membership as a graduate of the university. The university is an organization with a complex set of relationships in which social capital is embedded. Both students and graduates have degrees of access to the resources such membership in a university provides (e.g., job references).

Increasing numbers of international students are coming to the U.S. and other countries around the world. While a growing body of scholarship has focused on academic outcomes and retention, the nature and scope of the international students' development of social capital has remained largely unexplored. Research that exists has focused on social capital developed through engagement with conationals, other international students, and host country peers (Rose-Redwood and Rose-Redwood, 2013; Trice, 2004), but little research exists exploring the differences in these networks by specific organization type.

The current study examined campus organization involvement as a mechanism for social capital development. The concept of social capital was employed to answer the questions: (1) Is there a significant difference in the size, composition, strength, and density of networks for international students who participate in campus organizations? and (2) What are the significant differences in the size, composition, strength, and density of networks for international students who participate in specific types of campus organizations?

\section{Literature Review}

For the purposes of this study, social capital refers to resources available to people via social interaction (Bourdieu, 1986; Putnam, 2000). In other words, social capital involves sets of relationships which produce activity as people utilize the resources embedded in social networks to achieve their individual and collective goals (Lin, 2001). Social capital is created when shared experiences produce relationships of mutual concern (Robison and Siles, 2000).

As the name suggests, social capital involves "capital-like" properties where the mutual concern benefits a person or group beyond what might be exchanged among strangers, i.e. persons or groups who have no shared experience. Social capital operates in the same way as financial capital, with the exchange of socioemotional goods among persons substituting for the exchange of physical goods and services. Socioemotional goods take many forms but include such things as favors, advice, care, empathy, support, celebration, and information. Socioemotional goods might also be embedded in the exchange of 
objects among persons, such as when people exchange gifts, borrow lawn tools from a neighbor, etc.

Robison and Siles (2000) distinguish between earned and inherited "kernels of commonality" that lead to social capital (p. 2). Earned kernels are acquired through effort and involvement (e.g., membership in organizations, level of education, place of residence, etc.); whereas inherited kernels (e.g., gender, ethnicity, cultural heritage, nationality, etc.) are based on inherited characteristics. Social capital acquired through earned kernels has been associated with bridging capital that involves the exchange of ideas and information among networks of diverse persons but may not provide emotional support (Granovetter, 1973; Putnam, 2000). Social capital acquired through inherited kernels has been associated with bonding social capital that provides emotional support (e.g., from close friends and family members) but is generally less diverse (Phua and Jin, 2011; Putnam, 2000).

Social capital exists in networks of relationships (Robison and Ritchie, 2016). The social capital for which an individual has access to resides in a network of social relationships. However, it is insufficient to simply map connections among individuals. The social networks from which social capital is drawn may be characterized in terms of their composition (i.e., who is in the network), density (i.e. how interconnected the members of the network are with one another), size (i.e. how big the network is), and strength (i.e., the strength of the socioemotional goods exchanged). These patterns of relationships affect the resources available to a person and the distribution of the benefits those resources provide. When international students study abroad, their access to social capital is affected. To understand the international student experience, researchers must be aware of the network size, density, and composition of the social networks that provide access to resources for international students.

Although international students, by definition, are individuals who have crossed a national border for the purposes of formal study (UNESCO, 2012), international students are members of four types of networks that include the campus: academic program, and campus organizations, but often extend beyond the campus environment: family, and residential communities. The shared kernels of commonality among members of these four types of networks develop social capital that serves as the basis for the exchange of socioemotional goods, e.g. support, advice, care, favors, etc. In fact, such networks exist for the purposes of members to meet needs for support, celebration, validation, information, economic interests, etc. The combination of these four primary networks contributes to a "sense of place" for which an international student has an attachment. Attachment is evidenced by a sense of pride, allegiance, admiration, respect, commitment, and obligation to the organization for which one is a member.

The international student experience may be examined as the exchange of socioemotional goods among members in the four primary networks from which most students rely on to achieve their goals. Social capital is associated with increased satisfaction, enhanced self-esteem, greater involvement in campus life (Ellison et al., 2007), and campus engagement (Trice, 2004). Students with access to social capital have advantages that result in favorable exchanges that assist them in achieving their goals. The exchange of socioemotional goods, over time, validates a person's sense of attachment to the community. In 
other words, as members of these networks, students view themselves as being connected to one another, the exchange of socioemotional goods among members increases, creating an attachment to the community.

Campus organizations might reflect both inherited kernels of commonality (e.g., ethnic organizations of the student's own cultural heritage), and earned kernels of commonality (e.g., professional organizations, service organizations, etc.). Students also develop a sense of membership in an academic program based on earned kernels (e.g., earning a particular degree) but also rely on inherited kernels (e.g., studying with students with similar ethnic backgrounds). International students may live on-campus in residence halls made up of diverse individuals but a common identity (e.g., Scotland Hall); or international students may live off-campus in apartments composed primarily of students who share their national or ethnic background. Finally, international students might rely on advice from an older sibling about adjustment to life in the host country; or international students might form emotional support in regular phone calls with their parents.

As the result of targeted recruitment efforts, the number of international students on U.S. campuses has grown to over 1 million students (IIE, 2017) . Researchers have argued that increased compositional diversity alone is insufficient to realize the full benefits of increased international student enrollment (Glass et al., 2014). Although the advantages of a college credential are a primary factor in an international student's motivation to study in the U.S. (Choudaha, 2017; Glass et al., 2015), a significant outcome of college is also the social networks students build during their studies. In other words, a degree from a U.S. university does more than provide a credential that certifies knowledge. Universities are institutions that confer earned kernels of commonality among graduates. Those earned kernels result from the prestige of graduation from an academic program, as well as through social interaction that occurs in co-curricular organizations. However, research highlights that international students do not always engage as actively in co-curricular activities as their host country counterparts (Zhao et al., 2005).

Numerous studies highlight the importance of forming intercultural friendships in adapting to college life (Gareis, 2012), however little research has been conducted that accounts for the potential benefits those friendships provide in offering resources that help international students achieve their goals. Studies have documented that international students perceive greater constraints to engaging in out-of-class activities and develop fewer friendships with host national and international peers (Glass et al., 2014), and, consequently, feel less attached to their host institution (Poyrazli et al., 2004). More research is needed into understanding the mechanisms through which international students tap into the informal social life to gain access to resources that help them reach their goals, whether those goals be short-term (e.g., finding a ride to the grocery store, passing an exam, etc.) or long-term (e.g., building a network of future business partners, findings a job post-graduation, etc.) and the critical role of social support (Brannan et al., 2013).

Social capital provides a theoretical framework to understand how international students draw on resources available through campus organizations, academic programs, residential community, and family. Research demonstrates that international students who develop friendships with co-national and international peers have access to resources 
that facilitate their adaptation to college. It also provides a framework to understand specifically which types of organizations might serve as a gateway to cross-cultural friendships with host national and international peers Baba and Hosoda (2014). In other words, it provides actionable information that institutions and policymakers might use to invest in organizations associated with international students who develop social networks that are less dense, which provide valuable "bridging capital" that facilitates social mobility (Granovetter, 1973). Furthermore, it provides actionable information on the types of organizations that build "bonding capital" associated with attachment to a university. Numerous studies have demonstrated that belonging is a core aspect of an institution that fosters international students' resilience (Curtin et al., 2013; Yao, 2016). Finally, social capital provides a framework that is not university-centric. In other words, it allows an examination of the naturally occurring networks that exist within, but also beyond, the university's borders (McFaul, 2016; Rienties and Nolan, 2014; Rose-Redwood and Rose-Redwood, 2013).

\section{Research Method}

This study posed two research questions tested with an analysis of variance (ANOVA) with campus organization involvement as the independent variable and network size, composition, strength, and attachment as the dependent variables. This study examined campus organization involvement as a mechanism for social capital development. Accordingly, the researchers examined two questions:

RQ1: Is there a significant difference in the size, composition, strength, and density of networks for international students who participate in campus organizations?

RQ2: What are the significant differences in the size, composition, strength, and density of networks for international students who participate in specific types of campus organizations?

\section{Participants}

Seven hundred and sixty-one international students from a major U.S. research university were contacted through the Office of International Programs to complete a survey. Procedures associated with the study were reviewed and approved by the university's Institutional Review Board. Eligible participants received an e-mail which explained the purpose of the questionnaire, as well as issues related to confidentiality, anonymity, and consent. It included a link to the anonymous online survey instrument. Students did not receive incentives for participation. To protect participants' privacy, all individual identifiers were encrypted.

In all, 35\% ( $n=266)$ of eligible participants contacted agreed to participate in the study. Chi-square and ANOVA analysis indicated no significant differences between participants who were involved in campus organizations and those who were not by region of origin, gender, level of study, residential location, years in the U.S., grade point average, English proficiency, and academic performance. Therefore, the groups are comparable in terms of demographic factors. Table 1 includes descriptive statistics of participant demographics. 
Table 1. Demographics

\begin{tabular}{|c|c|c|c|c|}
\hline & $\begin{array}{l}\text { No Campus } \\
\text { Organization } \\
\text { Involvement } \\
\mathrm{n}(\%)\end{array}$ & $\begin{array}{l}\text { Involved in at } \\
\text { least } 1 \text { Campus } \\
\text { Organization } \\
\mathrm{n}(\%)\end{array}$ & Chi Square (df) & $p$ \\
\hline Region & & & $7.714(7)$ & .358 \\
\hline Europe & $20(23 \%)$ & $14(15 \%)$ & & \\
\hline $\begin{array}{l}\text { Sub-Saharan } \\
\text { Africa }\end{array}$ & $7(8 \%)$ & $3(3 \%)$ & & \\
\hline $\begin{array}{l}\text { North Africa and } \\
\text { Middle East }\end{array}$ & $15(18 \%)$ & $16(17 \%)$ & & \\
\hline East Asia & $5(6 \%)$ & $4(5 \%)$ & & \\
\hline South Asia & $10(12 \%)$ & $11(12 \%)$ & & \\
\hline South East Asia & $21(25 \%)$ & $27(29 \%)$ & & \\
\hline North America & $6(7 \%)$ & $13(14 \%)$ & & \\
\hline Oceania & $1(1 \%)$ & $4(5 \%)$ & & \\
\hline Gender & & & $2.733(2)$ & .255 \\
\hline Male & $39(48 \%)$ & $50(53 \%)$ & & \\
\hline Female & $42(52 \%)$ & $44(47 \%)$ & & \\
\hline Level & & & $7.105(6)$ & .311 \\
\hline Freshman & $9(11 \%)$ & $2(2 \%)$ & & \\
\hline Sophomore & $4(5 \%)$ & $7(8 \%)$ & & \\
\hline Junior & $7(8 \%)$ & $7(8 \%)$ & & \\
\hline Senior & $5(6 \%)$ & $7(8 \%)$ & & \\
\hline Graduate & $27(32 \%)$ & $34(35 \%)$ & & \\
\hline Doctoral & 33 (38\%) & $36(38 \%)$ & & \\
\hline Residence & & & $1.983(1)$ & .159 \\
\hline On-Campus & $13(15 \%)$ & $8(9 \%)$ & & \\
\hline \multirow[t]{2}{*}{ Off-Campus } & $72(85 \%)$ & $86(91 \%)$ & & \\
\hline & $\mathrm{M}(\mathrm{SD})$ & $\mathrm{M}(\mathrm{SD})$ & $\mathrm{F}(\mathrm{df})$ & $p$ \\
\hline Years in U.S. & $2.80(3.36)$ & $3.33(3.44)$ & 1.036 & .310 \\
\hline $\begin{array}{l}\text { Grade point } \\
\text { average }\end{array}$ & $3.50(.60)$ & $3.62(.49)$ & 1.809 & .181 \\
\hline $\begin{array}{l}\text { English profi- } \\
\text { ciency }\end{array}$ & 3.89 (1.06) & $4.13(.88)$ & 2.585 & .110 \\
\hline $\begin{array}{l}\text { Academic per- } \\
\text { formance }\end{array}$ & 3.43 (.99) & 3.61 (.99) & 1.491 & .224 \\
\hline
\end{tabular}




\section{Measures}

\section{Independent variable.}

The independent variable was participation in campus organizations. Participants indicated if they participated in campus organizations by responding to the question "Are you involved in any campus organizations?" ( $1=$ Yes; $0=$ No). If they indicated they were involved in campus organization they were asked the question, "What types of campus organizations have you been involved in during your studies in the U.S.? (select all that apply)" with checkbox options, including service, volunteer, or community organizations; professional or major-based organizations; leadership building programs and events; student government or advisory board meetings; ethnic organizations of own cultural heritage; ethnic organizations of another/mixed cultural heritage; club sports, intramural leagues, or recreation organizations; and student religious organizations.

\section{Dependent Variables.}

There were three dependent measures of campus organization, academic program, and neighborhood networks respectively: network size, composition, and strength, and there were two overall dependent measures: network density and attachment to the university. Table 2 contains all item wordings with their loadings and scale reliabilities. All alphas far exceeded the minimum required alpha of .70 (DeVellis, 2003).

The three dependent measures of campus organization, academic program, and neighborhood networks respectively were:

Network size. Network size was assessed using an empirically tested single-item measure that corresponds closely with detailed daily contact diary methods (Fu, 2005). Respondents were asked, "In a typical week, I stay in touch with about \# people in my ..." with separate prompts for campus organization, academic program, and neighborhood or residential community respectively with options to estimate: 0-4 people, 5-9 people, 1019 people, 20-49 people, and 50+ people; responses were coded with the average in the estimated range: $2,7,15,35$, and 50 respectively.

Network composition. Network composition was assessed with a 5-point Likert scale ( $1=$ Definitely not; $5=$ Definitely) of three single-item measures (i.e., friends from my own culture, international friends from other cultures, and friends from the U.S.) in response to the prompt, "Through ..., I tend to stay in touch with ..." Students responded to the three single-item measures with separate prompts for campus organizations, academic program, and neighborhood and residential community respectively.

Network strength. Network strength was assessed using a 9-item scale with social capital items developed by Robison and Siles (2000) with a 5-point Likert-scale (1=Definitely not; $5=$ Definitely) with separate prompts for campus organization $(\alpha=.94)$, academic program $(\alpha=.92)$, and neighborhood respectively ( $\alpha=.93$ ).

The two overall dependent measures were network density and attachment to the university:

Network density. Network density was assessed using a single-item developed by Davis et al. (2007): "When you think of all of the people that you stay in touch with on a regular basis, about how many of them know one another?" ( $5=$ almost all, $4=$ most know one 
Table 2. Factor loadings and reliabilities.

\begin{tabular}{|c|c|}
\hline Factor Scales and Item Wording & $(\alpha)$ Factor Loading \\
\hline Network Strength-Residence & $(.933)$ \\
\hline Share meals together & .930 \\
\hline Celebrate special occasions & .927 \\
\hline Socialize together & .921 \\
\hline Go places together & .922 \\
\hline Do favors for each other & .924 \\
\hline Borrow things from each other & .927 \\
\hline Assist each other if someone is sick & .923 \\
\hline Give useful advice & .927 \\
\hline Discuss struggles & .926 \\
\hline Network Strength-Academic Program & $(.921)$ \\
\hline Share meals together & .911 \\
\hline Celebrate special occasions & .913 \\
\hline Socialize together & .906 \\
\hline Go places together & .907 \\
\hline Do favors for each other & .912 \\
\hline Borrow things from each other & .907 \\
\hline Assist each other if someone is sick & .915 \\
\hline Give useful advice & .915 \\
\hline Discuss struggles & .916 \\
\hline Network Strength - Campus Organizations & $(.935)$ \\
\hline Share meals together & .933 \\
\hline Celebrate special occasions & .929 \\
\hline Socialize together & .924 \\
\hline Go places together & .924 \\
\hline Do favors for each other & .924 \\
\hline Borrow things from each other & .928 \\
\hline Assist each other if someone is sick & .928 \\
\hline Give useful advice & .928 \\
\hline Discuss struggles & .929 \\
\hline Attachment to the University & $(.908)$ \\
\hline pride & .887 \\
\hline allegiance & .886 \\
\hline admiration & .885 \\
\hline respect & .886 \\
\hline commitment & .895 \\
\hline obligation & .908 \\
\hline
\end{tabular}


another, $3=$ some know one another, $2=$ few know one another, or $1=$ almost none know one another).

Attachment. Attachment was assessed using a 6-item scale developed based on Robison and Siles (2000) in response to the prompt, "I have a strong sense of ... towards my university" with a 5-point Likert-scale ( 1 = strongly disagree; $5=$ strongly agree) to the items pride, allegiance, admiration, respect, commitment, and obligation $(\alpha=.91)$.

\section{Results}

Sixty-two percent of respondents did not participate in any campus organization; thirtyeight percent participated in one or more campus organizations. The three most common types of campus organizations that respondents participated in were service, volunteer, or community organizations (23 percent), professional or major-based organizations (20 percent), and ethnic organizations of their own cultural heritage (16 percent). Table 3 reports descriptive statistics for all dependent variables.

Researchers conducted ANOVA analysis to answer to question, "Is there a significant difference in the size, composition, strength, and density of networks for international students who participate in campus organizations?" Table 4 reports ANOVA results for international students who participated in at least one campus organization and those who did not participate in any campus organizations.

The analysis found a significant difference in the composition and strength for students who did and did not participate in campus organizations overall, but no difference in the size and density of the networks between the two groups. International students who participated in at least one campus organization interacted with U.S. friends in their academic program on a weekly basis more often than international students who did not participate in campus organizations. Moreover, international students who participated in at least one campus organization had greater social capital among friends in their neighborhood or residential community than international students who did not participate in campus organizations.

Researchers conducted ANOVA analysis to answer to question, "What are the significant differences in the size, composition, strength, and density of networks for international students who participate in specific types of campus organizations?" Table 5 reports significant ANOVA results for international students who participated in specific types of organization and those who did not participate in that type of campus organization.

International students who participated in service, volunteer, or community organizations interacted less frequently with friends from their own culture and reported greater social capital among friends in their academic program. Those who participated in professional or major-based organizations also reported greater social capital among friends in their academic program. They interacted more frequently with friends from the U.S. in their academic program and their neighborhood, and they interacted more frequently with international friends from other cultures in campus organizations.

Participation in leadership building programs and events by international students led to larger social networks on campus and in their neighborhood or residential community. These students interacted more frequently with friends from the U.S. in their campus organizations, and they had less dense social networks and a stronger attachment to 
Table 3. Descriptive statistics for all dependent variables.

\begin{tabular}{ll}
\hline & $\mathrm{M}(\mathrm{SD})$ \\
Residential Community-Network & \\
Size & $7.30(9.89)$ \\
Composition - Own Culture & $3.77(1.27)$ \\
Composition - International & $3.84(0.94)$ \\
Composition - U.S. & $3.84(0.99)$ \\
Strength & $3.47(0.98)$ \\
& \\
Academic Program - Network & \\
Size & $7.88(8.29)$ \\
Composition - Own Culture & $3.64(1.35)$ \\
Composition - International & $4.05(0.94)$ \\
Composition -U.S. & $4.05(0.98)$ \\
Strength & $3.61(0.88)$ \\
& \\
Campus Organizations - Network & \\
Size & $11.58(12.52)$ \\
Composition - Own Culture & $3.75(1.32)$ \\
Composition - International & $4.16(0.89)$ \\
Composition - U.S. & $4.15(0.95)$ \\
Strength & $3.94(0.86)$ \\
Family - Network & \\
Size & \\
Atrength & $6.55(9.78)$ \\
\hline & $4.25(1.04)$ \\
& \\
& \\
Network Density & \\
& \\
&
\end{tabular}

the university. While international students who participated in student government or advisory board meetings had larger social networks in their neighborhood or residential community.

International students who participated in ethnic organizations of another/mixed cultural heritage interacted less often with friends from their own culture in their neighborhood or residential community and friends from the U.S. in their academic program. While international students who participated in ethnic organizations of their own cultural heritage had larger campus networks and greater social capital among friends in campus organizations. Predictably, these students were more likely to interact with international students from their own cultural heritage on a weekly basis through campus 
Table 4. ANOVA results for students who participated in campus organizations and those who did not.

\begin{tabular}{|c|c|c|c|c|}
\hline No Campus & 1+ Campus Organization & $\mathrm{F}(\mathrm{df})$ & $p$ & $\eta 2$ \\
\hline $\begin{array}{l}\text { Organization } \\
\text { M (SD) }\end{array}$ & $\mathrm{M}(\mathrm{SD})$ & & & \\
\hline
\end{tabular}

\section{Academic Program}

\begin{tabular}{|c|c|c|c|c|c|c|}
\hline Size & 192 & $7.66(7.97)$ & $8.10(8.62)$ & $0.137(1)$ & 0.711 & .001 \\
\hline $\begin{array}{l}\text { Own } \\
\text { Culture }\end{array}$ & 191 & $3.57(1.33)$ & $3.71(1.37)$ & $0.529(1)$ & 0.468 & .003 \\
\hline $\begin{array}{l}\text { Interna- } \\
\text { tional }\end{array}$ & 191 & $3.98(0.95)$ & $4.12(0.92)$ & $1.090(1)$ & 0.298 & .006 \\
\hline U.S. & 193 & $3.83(1.05)$ & $4.25(0.87)$ & $9.315(1)$ & 0.003 & .047 \\
\hline Strength & 190 & $3.46(0.92)$ & $3.76(.81)$ & $5.377(1)$ & 0.211 & .028 \\
\hline \multicolumn{7}{|c|}{ Neighborhood/Residential Community } \\
\hline Size & 200 & $7.11(9.86)$ & $7.48(9.97)$ & $0.072(1)$ & 0.789 & .000 \\
\hline $\begin{array}{l}\text { Own } \\
\text { Culture }\end{array}$ & 200 & $3.70(1.28)$ & $3.84(1.25)$ & $0.570(1)$ & 0.451 & .003 \\
\hline $\begin{array}{l}\text { Interna- } \\
\text { tional }\end{array}$ & 202 & $3.79(0.94)$ & $3.88(0.95)$ & $0.420(1)$ & 0.518 & .002 \\
\hline U.S. & 201 & $3.72(1.05)$ & $3.95(0.91)$ & $2.675(1)$ & 0.103 & .013 \\
\hline Strength & 199 & $3.32(0.98)$ & $3.62(0.95)$ & $4.808(1)$ & 0.029 & .024 \\
\hline Density & 197 & $2.62(0.92)$ & $2.52(0.94)$ & $0.618(1)$ & 0.433 & .003 \\
\hline $\begin{array}{l}\text { Attach- } \\
\text { ment }\end{array}$ & 180 & $4.00(0.76)$ & $4.11(0.67)$ & $1.093(1)$ & 0.297 & .006 \\
\hline
\end{tabular}

organizations and their neighborhood or residential community, but they also interacted more frequently with friends from the U.S. and international friends from other cultures in their academic program.

Participation by international students in student-led religious organizations led to greater social capital among friends in their neighborhood or residential community. These students interacted more regularly with U.S. friends in that community. They also interacted with international friends from other cultures, and international friends from their culture in their academic program.

There were no significant differences in the network size, composition, strength, density, or attachment among international students who did and did not participate in club sports, intramural leagues, or recreation organizations. 
Table 5. ANOVA summary results of the significant differences between students who participated in specific types of campus organizations and those who did not.

\begin{tabular}{llllll}
\hline & $\begin{array}{l}\text { Did Not Participate } \\
\text { M (SD) }\end{array}$ & $\begin{array}{l}\text { Did Participate } \\
\text { M (SD) }\end{array}$ & F(df) & p & $\eta 2$ \\
service, volunteer, or community organizations & & & & \\
Campus-Own & $4.16(1.12)$ & $3.45(1.39)$ & $7.697(1)$ & .007 & .071 \\
Academic-Strength & $3.52(0.86)$ & $3.83(0.89)$ & $4.923(1)$ & .028 & .026 \\
& & & & & \\
professional or major-based organizations & & & & \\
Campus-Internation\$1.98 (0.94) & $4.33(0.82)$ & $4.128(1)$ & .045 & .039 \\
Academic-Strength & $3.52(0.87)$ & $3.87(0.85)$ & $6.251(1)$ & .013 & .032 \\
Academic-US & $3.95(1.01)$ & $4.31(0.86)$ & $5.258(1)$ & .023 & .027 \\
Residence-US & $3.75(1.05)$ & $4.08(0.74)$ & $4.179(1)$ & .042 & .021
\end{tabular}

leadership building programs and events

$\begin{array}{llllll}\text { Campus-Size } & 9.96(10.94) & 17.76(16.13) & 6.835(1) & .010 & .065 \\ \text { Campus-US } & 4.01(0.97) & 4.71(0.64) & 9.867(1) & .002 & .090 \\ \text { Residence-Size } & 6.64(8.47) & 12.86(17.30) & 7.664 & .006 & .037 \\ \text { Density } & 2.63(0.92) & 2.10(0.83) & 6.294 & .013 & .033 \\ \text { Attachment } & 4.01(0.73) & 4.39(0.51) & 5.025 & .026 & .027\end{array}$

ethnic organizations of their own cultural heritage

$\begin{array}{llllll}\text { Campus-Strength } & 3.74(0.86) & 4.26(0.78) & 9.579(1) & .003 & .089 \\ \text { Campus-Size } & 9.60(11.27) & 14.74(13.84) & 4.177(1) & .044 & .040 \\ \text { Campus-Own } & 3.43(1.36) & 4.28(1.08) & 11.013(1) & .001 & .099 \\ \text { Academic- } & 3.98(0.97) & 4.33(0.76) & 4.342(1) & .039 & .022 \\ \text { International } & & & & & \\ \text { Academic-US } & 3.95(0.99) & 4.40(0.87) & 6.750 & .010 & .034 \\ \text { Residence-Own } & 3.67(1.29) & 4.18(1.12) & 5.167 & .024 & .025\end{array}$

ethnic organizations of another/mixed cultural heritage

$\begin{array}{llllll}\text { Academic-US } & 4.00(0.99) & 4.47(0.77) & 4.062(1) & .045 & .021 \\ \text { Residence- } & 3.82(1.24) & 3.22(1.44) & 3.749(1) & .054 & .019 \\ \text { Own } & & & & & \end{array}$

student-led religious organizations

$\begin{array}{llllll}\text { Academic-Own } & 3.70(1.29) & 2.87(1.73) & 5.485(1) & .020 & .028 \\ \begin{array}{l}\text { Academic- } \\ \text { International }\end{array} & 4.01(0.95) & 4.53(0.64) & 4.348(1) & .038 & .022 \\ \begin{array}{l}\text { Academic-US } \\ \text { Residence- }\end{array} & 4.00(0.99) & 4.60(0.63) & & & \\ \text { Strength } & 3.43(0.97) & 3.96(0.96) & 4.296 & .022 & .027 \\ \text { Residence-US } & 3.79(0.99) & & & & \\ & & 4.40(0.83) & 5.392(1) & .021 & .026\end{array}$




\section{Discussion}

This study showed that international students who participated in campus organizations had a significant difference in the overall composition and strength of their networks, compared to students who did not participate in a campus organization. These students interacted with U.S. friends more often, and had greater social capital in their neighborhood than students who did not participate in campus organizations.

These results support previous studies showing that social connections can benefit international students' sense of belonging (Glass and Westmont, 2014) and positive attitudes and attachment to institutions (Mikhaylov and Fierro, 2015). The type of campus organizations in which students participated, effected the size, density and composition of their networks, with students involved in service-type organizations developing networks with friends from outside their own culture. This supports the research of Soria and Troisi (2014) indicating that the social connections built when interacting and developing friendships inside and outside the classroom can lead to greater comfort interacting with others from different cultures. These interactions not only affect student success and retention, but can result in the development of social capital.

Students who participated in campus organizations related to their own cultural heritage had networks built of friends from all cultures, creating a greater sense of belonging and attachment to the university. This attachment can affect students' feelings about their institution and the extent to which they feel embedded in the institutions' community (Johnson et al., 2001).

Students who participated in major-based organizations or leadership programs had larger, less dense, more diverse networks that are advantageous for accumulating resources and securing jobs. This supports Mikhaylov and Fierro (2015) study of international, undergraduate business students that found that participants used existing social capital to access networks in new locations. It also supports Rose-Redwood and Rose-Redwood (2013)findings that developing connections with other internationals expanded the global reach of post-graduation networks.

As institutions look for ways to maintain relationships with international alumni for purposes of recruitment and development, it is important that they understand the attachment of international alumni. The results indicate that development of social capital through student organizations increased social capital and attachment, however students' network strength, density, and diversity varied based on organization type. While some organizations led to greater sense of belonging and attachment while at the institution, others led to development of resources for successful career outcomes. This variance in network outcomes requires higher education institutions to gain a better understanding of students' higher education goals in order to connect students to organizations that provide the greatest personal benefit.

\section{Implications}

International students add value to the higher education environment academically, culturally, and financially making their presence on U.S. campuses a competitive priority (Altbach, 2004; Terrazas-Carrillo et al., 2014). Higher education professionals can 
use the results of this study to provide resources for international students that result in greater attachment to the institution. Providing resources can lead to strong emotional, structural, and relationship bonds between the school and its students that encourage commitment and attachment to the institution (Mbawuni and Nimako, 2015).

In order to retain international students and develop long term relationships with international alumni, institutions should consider including development of social capital into the comprehensive internationalization plan. By identifying places and contexts like student organizations that are conducive to developing social capital and strengthening attachment, institutions can increase international students' sense of belonging and attachment. As institutions gain greater understanding of how international students manage social capital, they may see a decrease in acculturative stress, a strengthening attachment to the institution, and improvement in job-seeking behaviors. Insights into the process of attachment could result in higher education institutions becoming more competitive in attracting international students (Terrazas-Carrillo et al., 2014), and in maintaining strong relationships with international alumni who benefit the institution financially.

This study is limited by a small sample from one institution where only $38 \%$ of study participants were involved in campus organizations. The results of this study should be interpreted within the context of a U.S. public, research university. Increasing the sample with questionnaire distribution to a diverse set of institutions will provide greater representation, and allow for comparison of results in order to make generalizations.

Future studies should be conducted to explore development of social capital and attachment based on students' geographic region of origin and region of study. Students who come from different social cultures may have greater or lesser reliance on each of the measures of social capital resulting in differing levels of attachment. Future studies on international student development of social capital in countries with non-western cultures should also be conducted, and may provide different results.

\section{References}

Adler, P. S. and Kwon, S. (2002). Social capital: Prospects for a new concept. The Academy of Management Review, 27(1):17-40.

Altbach, P. G. (2004). Higher education crosses borders. Change, 36(2):18-24.

Baba, Y. and Hosoda, M. (2014). Home away home: Better understanding of the role of social support in predicting cross-cultural adjustment among international students. College Student Journal, 48(1):1-15.

Beech, S. E. (2015). International student mobility: The role of social networks. Social \& Cultural Geography, 16(3):332-350.

Bourdieu, P. (1986). The forms of capital. volume 241, page 258, Westport, CT. Greenwood. Brannan, D., Biswas-Diener, R., Mohr, C. D., Mortazavi, S., and Stein, N. (2013). Friends and family: A cross-cultural investigation of social support and subjective well-being among college students. The Journal of Positive Psychology, 8(1):65-75.

Choudaha, R. (2017). Three waves of international student mobility, volume 42.

Curtin, N., Stewart, A. J., and Ostrove, J. M. (2013). Fostering academic self-concept: Advisor support and sense of belonging among international and domestic graduate 
students. American Educational Research Journal, 50(1):108-137.

Davis, J. A., Smith, T. W., and Marsden, P. V. (2007). General social surveys: Cumulative codebook: 1972-2006. NORC, Chicago, IL.

DeVellis, R. F. (2003). Scale development: Theory and applications. Sage Publications, Los Angeles.

Ellison, N. B., Steinfield, C., and Lampe, C. (2007). The benefits of Facebook 'friends': Social capital and college students' use of online social network sites. Journal of ComputerMediated Communication, 12(4):1143-1168.

$\mathrm{Fu}, \mathrm{Y}$. (2005). Measuring personal networks with daily contacts: A single-item survey question and the contact diary. Social Networks, 27(3):169-186.

Gareis, E. (2012). Intercultural friendship: Effects of home and host region. Journal of International and Intercultural Communication, 5(4):309-328.

Glass, C. R., Gesing, P., Hales, A., and Cong, C. (2017). Faculty as bridges to co-curricular engagement and community for first-generation international students. Studies in Higher Education, 42(5):895-910.

Glass, C. R., Gómez, E., and Urzua, A. (2014). Recreation, intercultural friendship, and international students' adaptation to college by region of origin. International Journal of Intercultural Relations, 42:104-117.

Glass, C. R., Kociolek, E., Wongtrirat, R., Lynch, R. J., and Cong, S. (2015). Uneven experiences: The impact of student-faculty interactions on international students' sense of belonging. Journal of International Students, 5(4):353.

Glass, C. R. and Westmont, C. M. (2014). Comparative effects of belongingness on the academic success and cross-cultural interactions of domestic and international students. International Journal of Intercultural Relations, 38(1):106-119.

Granovetter, M. S. (1973). The strength of weak ties. The American Journal of Sociology, 78(6):1360-1380.

IIE (2017). Open doors report on international educational exchange.

Johnson, Crosnoe, and Elder (2001). Students' attachment and academic engagement: The role of race and ethnicity. Sociology of Education, pages 318-340.

Lin, J. H., Peng, W., Kim, M., Kim, S. Y., and LaRose, R. (2011). Social networking and adjustments among international students. New Media \& Society, 14(3):421-440.

Lin, N. (2001). Social capital: A theory of social structure and action. Cambridge University Press, New York, NY.

Mbawuni, J. and Nimako, S. G. (2015). Critical factors underlying students' choice of institution for graduate programmes: Empirical evidence from Ghana. International Journal of Higher Education, 4(1):120-135.

McFaul, S. (2016). International students' social network: Network mapping to gage friendship formation and student engagement on campus. Journal of International Students, 6(1):1.

Mikhaylov, N. S. and Fierro, I. (2015). Social capital and global mindset. Journal of International Education in Business, 8(1):59-75.

Phua, J. and Jin, S. A. A. (2011). 'Finding a home away from home': the use of social networking sites by Asia-Pacific students in the United States for bridging and bonding social capital. Asian Journal of Communication, 21(5):504-519. 
Poyrazli, S., Kavanaugh, P. R., Baker, A., and Al-Timimi, N. (2004). Social support and demographic correlates of acculturative stress in international students. Journal of College Counseling, 7(1):73-82.

Putnam, R. D. (2000). Bowling alone: The collapse and revival of American community. Simon \& Schuster, New York, NY.

Rienties and Nolan (2014). Understanding friendship and learning networks of international and host students using longitudinal Social Network Analysis. International Journal of Intercultural Relations, 41:165-180.

Robison, L. J. and Ritchie, B. K. (2016). Relationship economics: The social capital paradigm and its application to business, politics and other transactions. Taylor \& Francis, New York, NY.

Robison, L. J. and Siles, M. E. (2000). Social capital: Sympathy, socio-emotional goods, and institutions.

Rose-Redwood and Rose-Redwood (2013). Self-Segregation or Global Mixing? Social Interactions and the International Student Experience. Journal of College Student Development, 54:413-429.

Soria, K. M. and Troisi, J. (2014). Internationalization at home alternatives to study abroad: Implications for students' development of global, international, and intercultural competencies. Journal of Studies in International Education, 18(3):261-280.

Terrazas-Carrillo, E. C., Hong, J. Y., and Pace, T. M. (2014). Adjusting to new places: International student adjustment and place attachment. Journal of College Student Development, 55(7):693-706.

Trice, A. G. (2004). Mixing it up: International graduate students' social interactions with American students. Journal of College Student Development, 45:671-687.

UNESCO (2012). UNESCO Institute for Statistics Glossary.

Yao, C. W. (2016). Unfulfilled expectations: Influence of Chinese international students' roommate relationships on sense of belonging. Journal of International Students, 6(3):762-778.

Zhao, C. M., Kuh, G. D., and Carini, R. M. (2005). A comparison of international student and American student engagement in effective educational practices. Journal of Higher Education, 76(2):209-231.

\section{Author biography}

Chris Glass Chris R. Glass is an Associate Professor in the College of Education, Old Dominion University. He takes a social psychological approach to researching international students with an interest in how the presence of others affects educational outcomes such as achievement, motivation, and social development.

Peggy Gesing Peggy Gesing is a Lecturer in the College of Education, Old Dominion University. She examines issues of global student mobility. 